Institut für Makroökonomie und Konjunkturforschung Macroeconomic Policy Institute

Working Paper

Lena Dräger ${ }^{1}$, Christian R. Proaño ${ }^{2}$

\title{
Cross-Border Banking and Business Cycles in Asymmetric Currency Unions
}

November 6, 2015

\begin{abstract}
Against the background of the emergence of macroeconomic imbalances within the European Monetary Union (EMU), we investigate in this paper the macroeconomic consequences of cross-border banking in monetary unions such as the euro area. For this purpose, we incorporate in an otherwise standard two-region monetary union DSGE model a global banking sector along the lines of Gerali et al. (2010), accounting for borrowing constraints of entrepreneurs and an internal constraint on the bank's leverage ratio. We illustrate in particular how rule-of-thumb lending standards based on the macroeconomic performance of the dominating region within the monetary union can translate into destabilizing spill-over effects into the other region, resulting in an overall higher macroeconomic volatility. Thereby, we demonstrate a channel through which the financial sector may have exacerbated the emergence of macroeconomic imbalances within the EMU. This effect may be partly mitigated if the central bank reacts to loan rate spreads, at least relative to the case with constant lending standards.
\end{abstract}

Keywords: Cross-border banking, euro area, monetary unions, DSGE, monetary policy

JEL classification: F41, F34, E52.

${ }^{1}$ University of Hamburg, Germany, lena.draeger@wiso.uni-hamburg.de

${ }^{2}$ University of Bamberg, Germany, christian.proano@uni-bamberg.de 


\title{
Cross-Border Banking and Business Cycles in Asymmetric Currency Unions
}

\author{
Lena Dräger*a and Christian R. Proaño ${ }^{b}$ \\ ${ }^{a}$ University of Hamburg, Germany \\ ${ }^{\mathrm{b}}$ University of Bamberg, Germany
}

November 6, 2015

\begin{abstract}
Against the background of the emergence of macroeconomic imbalances within the European Monetary Union (EMU), we investigate in this paper the macroeconomic consequences of crossborder banking in monetary unions such as the euro area. For this purpose, we incorporate in an otherwise standard two-region monetary union DSGE model a global banking sector along the lines of Gerali et al. (2010), accounting for borrowing constraints of entrepreneurs and an internal constraint on the bank's leverage ratio. We illustrate in particular how rule-of-thumb lending standards based on the macroeconomic performance of the dominating region within the monetary union can translate into destabilizing spill-over effects into the other region, resulting in an overall higher macroeconomic volatility. Thereby, we demonstrate a channel through which the financial sector may have exacerbated the emergence of macroeconomic imbalances within the EMU. This effect may be partly mitigated if the central bank reacts to loan rate spreads, at least relative to the case with constant lending standards.
\end{abstract}

Keywords: Cross-border banking, euro area, monetary unions, DSGE, monetary policy

JEL classification: F41, F34, E52.

\footnotetext{
*Corresponding author: lena.draeger@wiso.uni-hamburg.de. We would like to thank Zeno Enders, Philipp Engler, Mathias Hoffmann, Angela Abbate, Alexander Meyer-Gohde, Michael Paetz and Henning Weber for helpful comments and suggestions. The authors also thank Philipp Engler, Federico Signoretti and Andrea Gerali for sharing their code and Julia Lipp for excellent research assistance. This is a significantly revised version of Dräger and Proaño (2015). Part of this research was conducted while Christian R. Proaño was visiting the Research Centre of the Deutsche Bundesbank, the hospitality of which is gratefully acknowledged. The views expressed in this paper do not necessarily reflect those of the Deutsche Bundesbank. Financial support by the Hans-Böckler Foundation is gratefully acknowledged.
} 


\section{Introduction}

One of the central features of the European monetary unification process has been the steady integration of financial markets across the European Monetary Union (EMU) over the last three decades, which was embedded in an unprecedented financial globalization process (Lane and Milesi-Ferretti, 2007, European Commission, 2008, ECB, 2010). According to the textbook theory, more integrated financial markets improve portfolio diversification and facilitate the channeling of funds towards the more productive projects, thereby promoting better risk sharing and faster economic convergence across regions (Barro et al., 1995). However, the traditional view on financial globalization has been significantly relativized since the 2007 global financial crisis (see e.g. Kose et al., 2009 for a critical review). An alternative view stresses the importance of a potential link between financial integration and the emergence of financial bubbles and, thus, macroeconomic instability due to overly optimistic growth expectations and excessive cross-border private and public borrowing (Blanchard and Milesi-Ferretti, 2010 and Jaumotte and Sodsriwiboon, 2010).

The increased financial integration among EMU countries, driven by the elimination of currency risk, a fall in real interest rates in Southern European economies and the general economic integration, led to a surge in cross-border financial flows as shown in Figure 1. Given the well-known predominance of the banking sector in the European financial landscape, the expansion in cross-border financial activities took place primarily in the form of bank-related capital flows (BIS, 2010; Kleimeier et al., 2013). While initially economic convergence processes within EMU seemed to be related to the increase in financial integration, cross-border banking was also a driving factor for the credit booms and housing bubbles in some European countries such as Spain and Ireland, and thereby contributed to the build-up of intra-EMU current account imbalances (see e.g. Allen et al., 2011 and BIS, 2011).

Against this background, we investigate in this paper the role of cross-border bank credit flows in a two-region monetary union by incorporating a global banking sector in an otherwise standard two-country DSGE framework. Our model defines a financially constrained global bank with national branches in each region of the monetary union, where cross-border banking constitutes the allocation of loans to credit-constrained firms in each region. As the main contribution of the paper, we evaluate the macroeconomic consequences of cross-border banking under alternative lending standards. Based on recent empirical evidence from the euro area's bank lending survey which suggests that lending standards in the euro area have been procyclical in recent times (Čihák and Brooks, 2009), we assume that the global bank suffers from asymmetric information and thus sets its lending standards, measured by firms' required loan-to-value (LTV) ratio in each region, on the basis of the region's previous output gap. We contrast this scenario with an alternative rule-of-thumb scenario where the global bank sets a uniform lending standard for both regions on the basis of the previous output gap in the dominating region. Our model thus allows to evaluate the role of financial integration in the transmission and amplification of shocks throughout the monetary union through the lens of a bounded rationality 

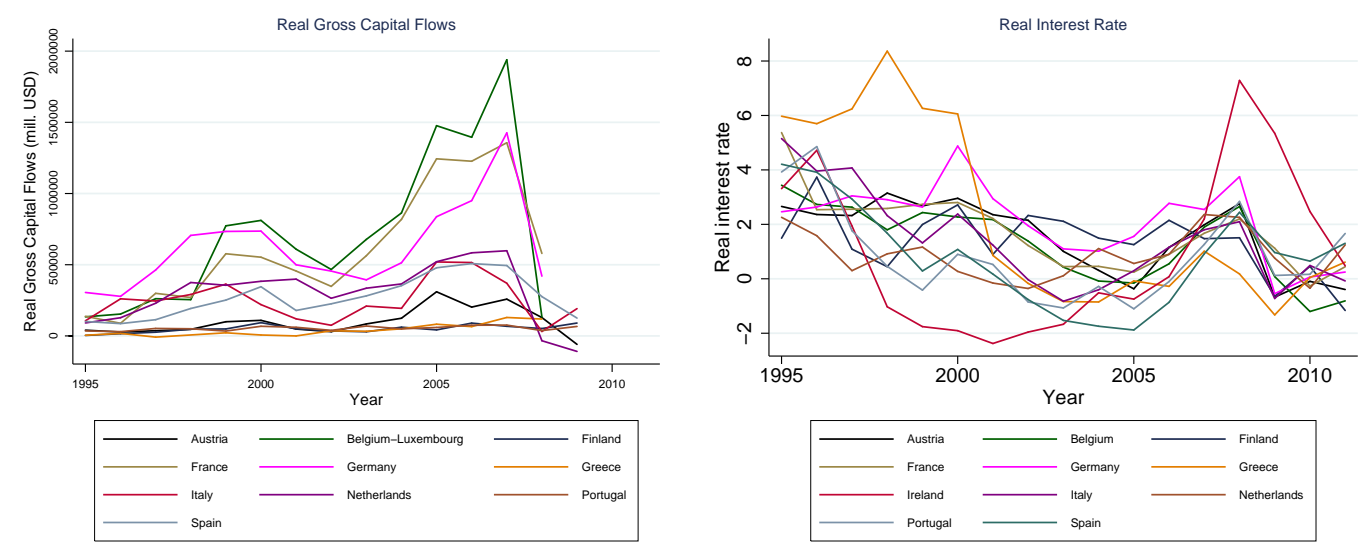

Figure 1: Real Total Gross Capital Flows and Real Interest Rates across EMU. Source: IMF Balance of Payments Statistics Yearbooks as assembled in Broner et al. (2013) and AMECO database.

environment.

Without aiming to deliver a complete explanation for the sizable capital inflows into some of the periphery countries of the EMU, this latter scenario is intended to capture the effect of interest rate convergence within EMU shown in Figure 1, where the elimination of currency risk effectively led financial markets to apply the low risk standards of the largest European economies throughout the whole monetary union. Following Gerali et al. (2010) and Gambacorta and Signoretti (2014), the banking sector is assumed to consist of a global wholesale branch, which underlies an exogenous constraint on the target leverage ratio and determines the amount of credit awarded in each region, and regional retail branches providing credit to entrepreneurs and collecting deposits from households. As in Iacoviello (2005), entrepreneurs are subject to a financial constraint where credit is awarded relative to their net worth, weighted with banks' desired LTV ratio as a measure for firms' creditworthiness.

Calibrating the model to the EMU, we first analyze the effect of a common monetary policy shock and a regional technology shock. Second, the nature of cross-border banking and trading flows in a monetary union with different LTV-based credit standards is evaluated. In the baseline scenario, bank's desired LTV ratio of firms is assumed to be constant and equal across regions. The baseline scenario may thus be regarded as capturing the case with symmetric information regarding firms' net worth in both regions. In the second scenario, the LTV ratio is driven by the region-specific previous output gaps. Thereby, a positive economic situation not only affects firms' net worth directly, but also serves as a signal for banks' assessment of firms' creditworthiness. Hence, in this scenario banks are assumed to suffer from asymmetric information which they cope with using the previous output gap as a signal. The effect of the shock on bank lending is amplified, and via the trade links between the regions, the whole monetary union is affected. In the third scenario, we assume that there exists 
one dominating region providing the signal for credit worthiness. This scenario may be regarded as capturing the convergence in risk-premia across EMU countries with the introduction of the common currency. Notably, macroeconomic volatility is highest in the third scenario.

In a nutshell, our simulation results highlight the role of cross-border lending under asymmetric information not only as an amplifying mechanism within a monetary union, but also as a potential source of macroeconomic instability. More precisely, while cross-border lending amplifies the effects of exogenous shocks in all three considered scenarios, in the latter one - where there is a dominant region which implicitly determines the lending standards for the whole monetary union - unified lending standards lead to the occurrence of business fluctuations in the periphery region driven purely by laxer credit conditions, and not by macroeconomic fundamentals. Hence, the financial sector may work to exacerbate the emergence of macroeconomic imbalances in a monetary union if banks assign lending standards from one dominating region to the whole monetary union. Analyzing alternatives for the conduction of monetary policy against this scenario, we find that a standard Taylor rule augmented by an intermediate loan spread target may generally increase the volatility of most macroeconomic variables, but is relatively more beneficial in the scenario with rule-of-thumb lending standards.

In modern DSGE models, the financial sector has only more recently received more attention. While models accounting for a financial accelerator as in Bernanke et al. (1999) or Iacoviello (2005) are now relatively common, most models do not feature a detailed banking sector. Recently, Gerali et al. (2010) set up a DSGE model with an imperfectly competitive banking sector subject to an internal leverage constraint and entrepreneurs facing a borrowing constraint. Estimating the model on euro area data, the authors report that shocks originating in the banking sector explain the largest share of the contraction of economic activity in 2008, while macroeconomic shocks play only a limited role. A similar result is obtained in Kollmann et al. (2011) in an estimated two-country model for the US and the euro area as well as in the empirical study by Kalemli-Ozcan et al. (2013). In a simplified version of the model by Gerali et al. (2010), Gambacorta and Signoretti (2014) analyse whether monetary policy should also target asset prices or credit in the presence of borrowing constraints on firms' side and a banking sector with a credit supply constraint. They show that leaning-against-the-wind policies by the central bank in reaction to supply side shocks allow for a better trade-off between output and inflation stabilization. Hence, the authors reinforce the results obtained by Cúrdia and Woodford (2010) in a much simpler model with exogenously introduced interest rate spreads. In the theoretical model of this paper, we build on the work of Gerali et al. (2010) and Gambacorta and Signoretti (2014) to evaluate the effect of borrowing and credit supply constraints in a two-region monetary union, focusing on spill-over effects of changes in cross-border lending standards between the regions.

Moreover, our paper is related to the models with cross-border banking and global banks in Ueda (2012), Kalemli-Ozcan et al. (2013), Kamber and Thoenissen (2013) and in 't Veld et al. (2014). Both Ueda (2012) and Kalemli-Ozcan et al. (2013) focus on the effect of real and financial shocks in two- 
country DSGE models with financially constrained national banks or a global bank, respectively, and report that financial shocks may cause an international synchronization of business cycles. More related to our approach, Kamber and Thoenissen (2013) incorporate a banking sector à la Gerali et al. (2010) into an international RBC model of a small open economy. The authors assume that banks in the small open home economy extend loans also to firms in the large foreign economy, and show that the propagation of foreign financial shocks to the home economy depends on the degree of financial integration of the domestic banking sector. The three-country New Keynesian model analyzed in in 't Veld et al. (2014) focuses on the emergence of international capital flows in a monetary union like the EMU. All of these previous approaches differ from ours in that we model cross-border lending via the specification of a financially constrained global bank with loan retail branches at the national level, and analyze the effects of changes in the banks' lending standards across the monetary union.

Finally, our approach is more broadly related to other two-region DSGE models of a monetary union, such as Benigno (2004), Gali and Monacelli (2008), Beetsma and Jensen (2005), Duarte and Wolman (2008), Ferrero (2009) and Engler et al. (2013). While the former three papers evaluate optimal monetary and fiscal policy rules in a monetary union, the latter three papers focus more specifically on problems related with fiscal policy in a monetary union, such as possibilities to improve inflation differentials with fiscal policy, or to use fiscal devaluation to counteract macroeconomic imbalances.

The remainder of this paper is organized as follows: In section 2 we set up a two-region DSGE model of a monetary union with a cross-border banking sector consisting of an international wholesale branch and region-specific retail branches as in Gerali et al. (2010) and Gambacorta and Signoretti (2014). In section 3 we discuss the properties of the resulting theoretical framework, and analyze the dynamic adjustments of the model's main variables to unexpected monetary policy and cost-push shocks, as well as the consequences of alternative specifications of the lending standards by the banking sector. In section 4 we investigate the design of monetary policy in such an environment. Finally, we draw some concluding remarks in section 5 .

\section{The Model}

We consider a two-region monetary union populated by a continuum of agents on the interval $[0,1]$, a segment $[0, n]$ residing in a region labeled $H$ (ome), and the other segment living in the other region labeled $F$ (oreign). We assume that Home is the risky region (the South, for the sake of illustration), and $F$ oreign is the safe-haven region (the North, for the sake of illustration). There is no labor mobility between the regions. Both regions are assumed to produce tradable consumption goods, which are considered to be imperfect substitutes due to a standard home bias argument. ${ }^{1}$ Since we model a monetary union, the nominal exchange rate between the regions is constant and may be normalised to one.

\footnotetext{
${ }^{1}$ Capital letters denote indices, small letters denote single units.
} 


\subsection{Households}

Households in both regions are infinitely-lived and have identical preferences and endowments within each region. Further, as in Iacoviello (2005) households are assumed to be more patient than entrepreneurs, that is, that they have a lower discount factor $\left(\beta<\beta_{E}\right)$. As a result, households purchase a certain amount of new deposit contracts and entrepreneurs borrow a positive amount of loans in equilibrium. In order to render the model stationary, we follow Schmitt-Grohé and Uribe (2003) and assume that households face a small quadratic portfolio adjustment $\operatorname{cost} \theta^{D}$ when their deposits differ from the steady-state level $\bar{D}$.

In a standard manner, the utility maximization problem of households in Home (analogous expressions apply for the Foreign households) is given by

$$
\max E_{t}\left[\sum_{s=t}^{\infty} \beta^{s}\left(\ln C_{s}^{H}-\frac{\left(N_{s}^{H}\right)^{\eta+1}}{\eta+1}\right)\right]
$$

subject to the real budget constraint

$$
C_{t}^{H}+D_{t}^{H}=\left(\frac{W_{t}^{H}}{P_{t}^{H}}\right) N_{t}^{H}+\frac{\left(1+r_{t-1}^{d}\right) D_{t-1}^{H}}{\pi_{t}^{H}}+\frac{\theta_{D}}{2}\left(D_{t}^{H}-\bar{D}\right)^{2}+\Pi_{t}^{H},
$$

where $C_{t}^{H}$ represents the households' aggregate consumption bundle (to be defined below), $N_{t}^{H}$ the households' labour supply, $D_{t}^{H}$ the interest-earning deposits, $\pi_{t}^{H} \equiv P_{t}^{H} / P_{t-1}^{H}$ the gross CPI inflation rate, $W_{t} / P_{t}^{H}$ the real wage and $\Pi_{t}^{H}$ the real profits from retailers in $H$, which are paid in a lumpsum manner to households. Households thus maximize the expected present discounted value of intertemporal utility, which we assume to be separable in consumption and leisure. Households in both $H$ ome and Foreign save in the form of bank deposits, earning a uniform deposit rate $r_{t}^{d}$ which for the sake of simplicity is assumed to be equal to the short-term interest rate controlled by the monetary authority of the currency union.

From the FOCs of this intertemporal optimization problem we obtain a consumption Euler equation and the standard labor supply equation:

$$
\frac{C_{t+1}^{k}}{C_{t}^{k}}=E_{t}\left(\frac{\beta\left(1+r_{t}^{d}\right)}{\pi_{t+1}^{k}\left[1-\theta_{D}\left(D_{t}^{k}-\bar{D}\right)\right]}\right)
$$

and

$$
\left(N_{t}^{k}\right)^{\eta}=\frac{W_{t}^{k}}{C_{t}^{k} P_{t}^{k}}
$$

with $k=\{H, F\}$, as the households in Foreign are assumed to have symmetric intertemporal preferences.

Following Duarte and Wolman (2008) and Ferrero (2009), the aggregate consumption bundle in Home (analogous expressions hold for Foreign) contains region-specific goods bundles from both regions and is defined as

$$
C_{t}^{H}=\left[\left(1-\omega^{H}\right)^{\frac{1}{\sigma}}\left(C_{t}^{h}\right)^{\frac{\sigma-1}{\sigma}}+\left(\omega^{H}\right)^{\frac{1}{\sigma}}\left(C_{t}^{f}\right)^{\frac{\sigma-1}{\sigma}}\right]^{\frac{\sigma}{\sigma-1}}
$$


where $C_{t}^{h}$ and $C_{t}^{f}$ represent bundles of retail consumption goods $i$ produced in Home and Foreign, respectively, $\sigma$ denotes the elasticity of substitution between these two consumption bundles and the parameter $\omega^{H}$ represents the steady-state import share of households in $H$. Given our assumption of home bias in consumption, it holds that $\omega^{H}<(1-n) .^{2}$

Assuming that the law of one price holds and fixing the nominal exchange rate at one, retail prices for individual goods will be the same in both regions: $P_{t}^{h}=P_{t}^{h *}$ and $P_{t}^{f}=P_{t}^{f *}$. From the demand functions for individual goods and defining the terms of trade as $T_{t} \equiv P_{t}^{f} / P_{t}^{h}$, it is straightforward to derive expressions for relative prices in $H$ and $F$, and the resulting real exchange rate:

$$
R E R_{t}=\frac{P_{t}^{F}}{P_{t}^{H}}=T_{t}\left(\frac{\left(1-\omega^{F}\right)+\omega^{F} T_{t}^{\sigma-1}}{\left(1-\omega^{H}\right)+\omega^{H} T^{1-\sigma}}\right)^{\frac{1}{1-\sigma}}
$$

where $P_{t}^{H} \equiv\left[\left(1-\omega^{H}\right)\left(P_{t}^{h}\right)^{1-\sigma}+\omega^{H}\left(P_{t}^{f}\right)^{1-\sigma}\right]^{\frac{1}{1-\sigma}}$ denotes the CPI price index in $H$ and accordingly for $F .^{3}$

\section{$2.2 \quad$ Firms}

Production is assumed to take place in two stages. In the first stage, firms in region $H$ and firms in region $F$ produce the intermediate good $Y_{t}^{h, i n t}$ and $Y_{t}^{f, i n t}$ in fully competitive markets and under credit constraints as in Iacoviello (2005). In line with Bernanke et al. (1999), we then assume that intermediate goods are sold to retailers, who take their price as given and differentiate them at no cost. Due to the differentiation of products, retailers are assumed to operate under monopolistic competition and face a quadratic cost for the adjustment of prices as in Rotemberg (1982). All profits from retail activities are rebated lump-sum to households in the respective region.

\subsubsection{Entrepreneurs}

Entrepreneurs in regions $H$ and $F$ produce intermediate goods $Y_{t}^{h, \text { int }}$ and $Y_{t}^{f, \text { int }}$ under perfect competition. Intermediate goods are used in the production of a final consumption good and are assumed to be non-tradable. Entrepreneurs aim at maximizing their consumption and use capital goods and labor for the production of intermediate goods. We assume that entrepreneurs consume only goods from their own region. At the end of each period, entrepreneurs buy new capital goods from capital producers, so that capital is only realized in the next period. Investment into new capital goods

\footnotetext{
${ }^{2}$ Note that the assumption of a symmetric steady state with equal per-capita output in the two regions implies that the amount of home bias in both regions is related to the relative region size: $\omega^{F}=\frac{n}{1-n} \omega^{H}$.

${ }^{3}$ Note that given the assumed home bias in consumption, the households' aggregate consumption bundles in $H$ ome and Foreign and the corresponding price indices are not necessarily symmetric. For detailed derivations, we refer to the previously referred papers, and to the online appendix of this paper.
} 
is assumed to be financed with loans from banks. ${ }^{4}$ Following Iacoviello (2005), we assume that entrepreneurs are credit-constrained due to the risk of default on their loans and thus can only borrow up to a fraction of their collateral, i.e. their capital assets. The resulting dynamics are similar to a financial accelerator effect as in Bernanke et al. (1999). Note that our assumption of a lower discount factor for firms ensures that the borrowing constraint will always bind in the neighbourhood of the steady-state.

Entrepreneurs in $H$ thus maximize consumption $C_{t}^{E H}$ subject to their budget and their borrowing constraints and to a Cobb-Douglas constant-returns-to-scale production function:

$$
\max E_{0} \sum_{t=0}^{\infty} \beta_{E}^{t} \ln C_{t}^{E H}
$$

s.t.

$$
\begin{gathered}
C_{t}^{E H}+\frac{\left(1+r_{t-1}^{b H}\right)}{\pi_{t}^{H}} B_{t-1}^{E H}+\left(\frac{W_{t}^{H}}{P_{t}^{H}}\right) N_{t}^{d H}+q_{t}^{K H} K_{t}^{H} \leq \frac{Y_{t}^{h, i n t}}{\mu_{t}}+B_{t}^{E H}+q_{t}^{k H}\left(1-\delta^{k}\right) K_{t-1}^{E H} \\
B_{t}^{E H} \leq \frac{m^{E} q_{t+1}^{k H}\left(1-\delta^{k}\right) K_{t}^{E H} \pi_{t+1}^{H}}{1+r_{t}^{b H}} \\
Y_{t}^{h, \text { int }}=A_{t}^{H}\left(K_{t-1}^{E H}\right)^{\xi}\left(N_{t}^{d H}\right)^{(1-\xi)}
\end{gathered}
$$

where $C_{t}^{E H}$ is entrepreneurs' consumption in $H, B_{t}^{E H}$ is the amount borrowed from banks at the loan rate $\left(1+r_{t}^{b H}\right), N_{t}^{d H}$ is the amount of labor demanded by entrepreneurs, $\mu_{t} \equiv P_{h, t} / P_{t}^{h, \text { int }}$ denotes the mark-up of retail over intermediate goods prices (we assume that the mark-up is the same in both regions), $K_{t}^{E H}$ is capital obtained at the price $q_{t}^{k H}$ and depreciated with rate $\delta^{k}$. Entrepreneurs' discount factor $\beta_{E}$ is assumed to be lower than households' $\beta$, so that entrepreneurs are always net borrowers. The Cobb-Douglas production function gives output as a function of capital and labour inputs, where $A_{t}^{H}$ is an exogenous technology process which may differ across regions. We define $A_{t}^{H}$ as an exogenous $\operatorname{AR}(1)$ process with persistence parameter $\rho_{a}$ and i.i.d. shock process $\varepsilon_{t}^{A H}$.

The borrowing constraint in (9) states that loans cannot exceed a fraction $m^{E}$ of the real depreciated value of capital assets in relation to the interest obligations in order to mitigate potential losses from loan default as in the seminal financial accelerator model by Bernanke et al. (1999). The parameter $m^{E}$ may be interpreted as the loan-to-value (LTV) ratio that banks demand of entrepreneurs and, thus, gives a measure of banks' assessment regarding firms' credit worthiness. We assume that $m^{E}$ may vary across regions in the monetary union, reflecting different macroeconomic conditions and different assessments of firms' credit worthiness by banks. While the baseline simulation assumes symmetric borrowing constraints in both regions, in section 3.4 we assume that banks relate the firms'

\footnotetext{
${ }^{4}$ This seems to be a reasonable assumption for a model of the EMU, since bank credit is the predominant source of external finance for European firms, see for instance Allen et al. (2011).
} 
credit worthiness with the past aggregate macroeconomic performance, i.e. the previous output gap of the corresponding region. In a first extension of the model, we thus assume that the strength of each region's borrowing constraint is influenced by the previous observed output gap. In a second extension, we assume that there exists one dominating region in the monetary union whose business cycle stance is taken as a measure of credit worthiness for the whole monetary union instead. This may be motivated by the perception of the financial sector that upon entering into a monetary union, the riskiness of loans in all regions is reduced to that of the dominating region as could be witnessed with the reduction in loan spreads between the North and the Southern regions upon entering into EMU.

Defining the real return of capital as $R_{t}^{k H} \equiv \frac{\xi A_{t}^{H}\left(K_{t-1}^{E H}\right)^{\xi-1}\left(N_{t}^{d H}\right)^{(1-\xi)}}{\mu_{t}}$ we then get the following optimality conditions:

$$
\begin{aligned}
\frac{1}{C_{t}^{E H}}-s_{t}^{B} & =\frac{\beta_{E}\left(1+r_{t}^{b H}\right)}{\pi_{t+1}^{H}} C_{t+1}^{E H} \\
\frac{q_{t}^{k H}}{C_{t}^{E H}} & =\frac{\beta_{E}}{C_{t+1}^{E H}}\left[R_{t+1}^{k H}+q_{t+1}^{k H}\left(1-\delta^{k}\right)\right]+\frac{s_{t}^{B} m^{E} q_{t+1}^{k H}\left(1-\delta^{k}\right) \pi_{t+1}^{H}}{1+r_{t}^{b H}} \\
\frac{W_{t}^{H}}{P_{t}^{H}} & =\frac{(1-\xi) Y_{t}^{h, i n t}}{N_{t}^{d H} \mu_{t}}
\end{aligned}
$$

Equation (11) gives entrepreneurs' Euler equation, where $s_{t}^{B}$ denotes the Lagrange multiplier on the borrowing constraint and thus gives the marginal value of one unit of borrowing. The relation in (12) gives the optimal relation between entrepreneurs' consumption and real returns from capital, given the borrowing constraint. Finally, equation (13) shows that in the optimum, real wages equal the marginal product of labor. Analogous optimality conditions hold for entrepreneurs in region F.

\subsubsection{Capital producers}

As in Gerali et al. (2010) and Gambacorta and Signoretti (2014), we assume that each period, capital production is undertaken by perfectly competitive capital producers, which are owned by entrepreneurs. These firms buy last period's depreciated capital stock from entrepreneurs as well as an investment $I_{t}$ in the form of new final goods from retailers and use both to produce the new capital stock. In line with previous authors, we assume that old capital stock can be transformed one-for-one into new capital stock, while investment from final goods underlies a quadratic adjustment cost for the transformation into capital goods. At the end of the period, the resulting new capital stock is sold back to entrepreneurs. Since capital goods production takes place within each region, we only describe the problem for capital goods producers in $H$, but analogous relations hold also in $F$ :

Defining $\Delta \bar{x}_{t}^{H} \equiv K_{t}^{E H}-\left(1-\delta^{k}\right) K_{t-1}^{E H}$, capital goods producers then solve the following problem:

$$
\max _{\Delta \bar{x}_{t}^{H}, I_{t}^{H}} E_{0} \sum_{t=0}^{\infty} \Lambda_{k, t}^{E H}\left[q_{t}^{k H} \Delta \bar{x}_{t}^{H}-I_{t}^{H}\right]
$$


s.t.

$$
\Delta \bar{x}_{t}^{H}=\left[1-\frac{\kappa^{I}}{2}\left(\frac{I_{t}^{H}}{I_{t-1}^{H}}-1\right)^{2}\right] I_{t}^{H}
$$

where $\Lambda_{k, t}^{E H} \equiv \beta_{E}^{k} U^{\prime}\left(C_{t+k}^{E H}\right)=\beta_{E}^{k} \lambda_{t+k}^{E H}$, with $k=0,1, \ldots$, is the stochastic discount factor from entrepreneurs, who are assumed to own capital producing firms, and $\lambda_{t}^{E H}$ is the Lagrange multiplier on entrepreneur's budget constraint. The capital adjustment cost is denoted by $\kappa^{I}$, which we assume to be equal across regions. The FOCs then yield an expression determining the price of real capital, $q_{t}^{k H}$ :

$$
1=q_{t}^{k H}\left(1-\frac{\kappa^{I}}{2}\left(\frac{I_{t}^{H}}{I_{t-1}^{H}}-1\right)^{2}-\kappa^{I}\left(\frac{I_{t}^{H}}{I_{t-1}^{H}}-1\right) \frac{I_{t}^{H}}{I_{t-1}^{H}}\right)+\beta_{E} E_{t}\left(\frac{\lambda_{t+1}^{E H}}{\lambda_{t}^{E H}} q_{t+1}^{k H} \kappa^{I}\left(\frac{I_{t+1}^{H}}{I_{t}^{H}}-1\right)\left(\frac{I_{t+1}^{H}}{I_{t}^{H}}\right)^{2}\right)
$$

\subsubsection{Retailers}

Retailers in regions $H$ and $F$ buy intermediate goods $Y_{t}^{h, i n t}$ or $Y_{t}^{f, i n t}$ from entrepreneurs in a competitive market, taking their price $P_{t}^{h, i n t}$ or $P_{t}^{f, i n t}$ as given. These intermediate goods are then differentiated into final consumption goods at no cost, so that retailers operate under monopolistic competition. Additionally, they are assumed to face quadratic costs for the adjustment of prices as in Rotemberg (1982). In our two-region model, retailers are symmetric, but face demand from consumers in both regions as well as from domestic entrepreneurs.

Aggregating over households and entrepreneurs, world demand for individual retail goods for retailers in $H$ is then derived from the demand equations of households and from entrepreneurs, measured in units per domestic firm. Note that we model the elasticity of substitution for individual goods produced in $H$ as a region-specific exogenous process $\varepsilon_{t}^{H}$. This gives the demand for individual good $Y_{t}^{h}(i)$, faced by a retailer in $H$ (again, analogous relations apply for retailers in $F$ ):

$$
\begin{aligned}
& Y_{t}^{h, \text { total }}(i)=\left(\frac{P_{t}^{h}(i)}{P_{t}^{h}}\right)^{-\varepsilon_{t}^{H}}\left[(1-\lambda)\left[\left(1-\omega^{H}\right)\left(\frac{P_{t}^{h}}{P_{t}^{H}}\right)^{-\sigma} C_{t}^{H}+\omega^{F} \frac{1-n}{n}\left(\frac{P_{t}^{h}}{P_{t}^{F}}\right)^{-\sigma} C_{t}^{F}\right]+\lambda C_{t}^{E H}\right] \\
& Y_{t}^{h, \text { total }}(i)=\left(\frac{P_{t}^{h}(i)}{P_{t}^{h}}\right)^{-\varepsilon_{t}^{H}} C_{t}^{W H}
\end{aligned}
$$

where $C_{t}^{W H}$ denotes aggregate world demand for retail goods from region $H$ and $F$, respectively, and $\lambda$ is the share of entrepreneurs in the economy. Individual retailers in $H$ set the price $P_{t}^{h}(i)$ for the individual final good $Y_{t}^{h}(i)$, and thus face the following maximization problem:

$$
\max _{P_{t}^{h}(i)} E_{t} \sum_{t=0}^{\infty} \Lambda_{k, t}^{H H}\left[\frac{P_{t}^{h}(i)}{P_{t}^{h}} Y_{t}^{h, \text { total }}(i)-\frac{P_{t}^{h, \text { int }}}{P_{t}^{h}} Y_{t}^{h, \text { total }}(i)-\frac{\kappa_{p}}{2}\left(\frac{P_{t}^{h}(i)}{P_{t-1}^{h}(i)}-1\right)^{2} C_{t}^{W H}\right],
$$

where $\Lambda_{k, t}^{H H} \equiv \beta^{k} U^{\prime}\left(C_{t+k}^{H}\right)=\beta^{k} \lambda_{t+k}^{H H}$, with $k=0,1, \ldots$, is the stochastic discount factor from households' utility maximization in $H, \pi_{t}^{h}=P_{t}^{h} / P_{t-1}^{h}$ defines retail price inflation and $\kappa_{p}$ denotes the 
adjustment cost for changing prices. The maximization problem is subject to total demand for the final good as derived above in (17).

Imposing a symmetric equilibrium, this yields the following optimality condition:

$$
1-\varepsilon_{t}^{H}+\frac{\varepsilon_{t}^{H}}{\mu_{t}}-\kappa_{p} \pi_{t}^{h}\left(\pi_{t}^{h}-1\right)+\beta \kappa_{p} E_{t}\left[\frac{\lambda_{t+1}^{H H}}{\lambda_{t}^{H H}} \frac{C_{t+1}^{W H}}{C_{t}^{W H}} \pi_{t+1}^{h}\left(\pi_{t+1}^{h}-1\right)\right]=0
$$

Finally, the exogenous process for the elasticity of substitution is related to retailers' mark-up $m k_{t}^{H}$ in region $H$ via the relation $m k_{t}^{H}=\varepsilon_{t}^{H} /\left(\varepsilon_{t}^{H}-1\right)$. We model retailers' region-specific mark-up as an $\operatorname{AR}(1)$ process with persistence $\rho_{m k}$ and an i.i.d. cost-push shock $\varepsilon_{t}^{Y H}$.

\subsection{The Banking Sector}

Building on the models by Gerali et al. (2010) and Gambacorta and Signoretti (2014), we assume that there exists a representative bank in the monetary union, which consists of an international wholesale branch and national retail branches in each region of the monetary union. The bank may thus be regarded as a global bank as for instance in Kalemli-Ozcan et al. (2013). The wholesale branch decides upon credit conditions in each region by setting the lending standards of entrepreneurs' credit constraint as well as the loan rates and thus governs cross-border lending. In that sense, the banking sectors within the monetary union are assumed to be completely integrated.

The wholesale branch is responsible for collecting deposits from households throughout the monetary union and distributes the resulting funds to the retail branches at the internal loan rates $R^{b H}$ and $R^{b F}$. The retail branches then provide credit to entrepreneurs in their region of residence. Note that in this set-up, banks cannot endogenously create new credit. The wholesale branch is additionally responsible for adhering to the exogenous constraint on the bank's leverage ratio, which is modelled in the form of a quadratic cost of deviating from the target value $\nu$. The value of $\nu$ could for instance be interpreted as reflecting regulatory legislation regarding banks' equity holdings. The credit-supply channel thus introduces an additional feedback loop between real and financial conditions in the sense that the loan rates, as well as the spread between the loan rates and the risk-free policy rate, depends on banks' leverage, their profit and, hence, on macroeconomic conditions. Finally, retail branches in $H, F$ are assumed to operate under monopolistically competitive conditions, and thus charge a constant mark-up $\bar{\mu}^{b}$ on the internal loan rate $R^{b H}$, i.e. $R^{b F}$.

Aggregate deposits in the monetary union and aggregate lending to entrepreneurs in both regions are defined as follows:

$$
\begin{aligned}
D_{t} & \equiv n D_{t}^{H}+(1-n) D_{t}^{F} \\
B_{t} & \equiv\left[n^{\frac{1}{\gamma}}\left(B_{t}^{H}\right)^{\frac{\gamma-1}{\gamma}}+(1-n)^{\frac{1}{\gamma}}\left(B_{t}^{F}\right)^{\frac{\gamma-1}{\gamma}}\right]^{\frac{\gamma}{\gamma-1}}
\end{aligned}
$$


where $B_{t}^{H}$ and $B_{t}^{H}$ denote the credit supply given to retail branches in region $H$ and $F$, respectively, and $\gamma$ denotes the bank's elasticity of substitution between lending to both regions. We thus assume that loans to the two regions are imperfect substitutes from the point of view of the bank, which may be motivated with the notion of a historically more sound economic performance in one region (here the North), as well as with differences in the credit screening capabilities in both regions. Note that we assume no home bias in lending, because the wholesale bank is assumed to be international. In our set-up, the wholesale branch thus aims at maximizing profits subject to a quadratic cost for deviating from their target leverage ratio $\nu$ and to their budget constraint:

$$
\max n R_{t}^{b H} B_{t}^{H}+(1-n) R_{t}^{b F} B_{t}^{F}-r_{t}^{d} D_{t}-\frac{\theta}{2}\left(\frac{K_{t}^{b}}{B_{t}}-\nu\right)^{2} K_{t}^{b}
$$

s.t.

$$
\begin{aligned}
& B_{t}=D_{t}+K_{t}^{b} \\
& B_{t}=\left[n^{\frac{1}{\gamma}}\left(B_{t}^{H}\right)^{\frac{\gamma-1}{\gamma}}+(1-n)^{\frac{1}{\gamma}}\left(B_{t}^{F}\right)^{\frac{\gamma-1}{\gamma}}\right]^{\frac{\gamma}{\gamma-1}},
\end{aligned}
$$

where $K_{t}^{b}$ is the banks' own capital and the parameter $\theta$ gives the proportion of $K_{t}^{b}$ to which the cost of deviating from target applies. The bank's leverage ratio and its budget constraint are determined with respect to aggregate lending $B_{t}$. Solving the maximization problem gives the internal loan rates for credit supply to retail branches in regions $H$ and $F$ :

$$
\begin{aligned}
& R_{t}^{b H}=n^{\frac{1-\gamma}{\gamma}} r_{t}^{d}\left(\frac{B_{t}}{B_{t}^{H}}\right)^{\frac{1}{\gamma}}-n^{\frac{1-\gamma}{\gamma}} \theta\left(\frac{K_{t}^{b}}{B_{t}}-\nu\right) \frac{\left(K_{t}^{b}\right)^{2}}{B_{t}^{\frac{2 \gamma+1}{\gamma}}\left(B_{t}^{H}\right)^{\frac{1}{\gamma}}} \\
& R_{t}^{b F}=(1-n)^{\frac{1-\gamma}{\gamma}} r_{t}^{d}\left(\frac{B_{t}}{B_{t}^{F}}\right)^{\frac{1}{\gamma}}-(1-n)^{\frac{1-\gamma}{\gamma}} \theta\left(\frac{K_{t}^{b}}{B_{t}}-\nu\right) \frac{\left(K_{t}^{b}\right)^{2}}{B_{t}^{\frac{2 \gamma+1}{\gamma}}\left(B_{t}^{F}\right)^{\frac{1}{\gamma}}}
\end{aligned}
$$

Hence, extending the closed economy set-up in Gambacorta and Signoretti (2014) to the open economy case, it turns out that both the effect of the risk-free deposit rate and of the leverage constraint on the loan rate are weighted with the relative share of loan supply to the respective region, adjusted for region size. This means that loan rates in a given region will be more sensitive to deviations from the bank's leverage target and to changes in the policy rate if the wholesale branch distributes a larger share of its overall credit supply to this region.

As in Gambacorta and Signoretti (2014), the retail banks are then assumed to be able to differentiate the wholesale loans at no costs and pass them under monopolistic competition on to entrepreneurs, charging a constant mark-up $\bar{\mu}^{b}$, which we assume to be equal across regions in the monetary union: ${ }^{5}$

$$
\begin{aligned}
& r_{t}^{b H}=R_{t}^{b H}+\bar{\mu}^{b} \\
& r_{t}^{b F}=R_{t}^{b F}+\bar{\mu}^{b}
\end{aligned}
$$

\footnotetext{
${ }^{5}$ This assumption implies that throughout the monetary union, the market structure among retail banks is similar. Since we assume that the representative bank acts internationally in both regions of the monetary union, this assumption seems reasonable.
} 
Finally, we define aggregate banks' profits $J_{t}^{b}$ as the sum of wholesale and retail profits and assume that banks re-invest their profits into new bank capital, where a fraction $\delta^{b}$ is used each period to pay for banking activities:

$$
\begin{aligned}
J_{t}^{b} & =n r_{t}^{b H} B_{t}^{H}+(1-n) r_{t}^{b F} B_{t}^{F}-r_{t}^{d} D_{t}-\frac{\theta}{2}\left(\frac{K_{t}^{b}}{B^{t}}-\nu\right)^{2} K_{t}^{b} \\
K_{t}^{b} & =\left(1-\delta^{b}\right) K_{t-1}^{b}+J_{t-1}^{b}
\end{aligned}
$$

\subsection{Monetary Policy}

The central bank in the model controls the nominal risk-free interest rate $r_{t}^{d}$ and adjusts to inflation as in Bernanke et al. (1998). Since we model a currency union, the central bank targets inflation in both regions, where the weight is given by their relative size. This results in the following Taylor-type rule:

$$
\left(1+r_{t}^{d}\right)=\left(1+r_{t-1}^{d}\right)^{\rho}\left(1+\bar{r}^{d}\right)^{1-\rho}\left(\left[n\left(\pi_{t}^{H}\right)+(1-n)\left(\pi_{t}^{F}\right)\right]^{\phi_{\pi}}\right)^{1-\rho} \varepsilon_{t}^{r d}
$$

where $\rho$ measures the amount of interest rate smoothing, $\bar{r}^{d}$ the nominal steady state interest rate, $\phi_{\pi}$ gives the strength of inflation targeting and $\varepsilon_{t}^{r d}$ is an i.i.d. monetary policy shock.

\section{Simulations}

\subsection{Calibration}

For the following simulations we follow Gambacorta and Signoretti (2014) and set our model parameters mainly as in Gerali et al. (2010), who calibrated their model so as to match key aspects of the euro area real and financial sectors. Additionally, some parameters relating to the open-economy aspect of the model are calibrated as in the two-region model of the euro area of Engler et al. (2013). Table 1 reports all parameter values. ${ }^{6}$

Accordingly, households' discount factor $\beta_{P}$ is set at 0.996 , which implies a steady-state policy rate of about $2 \%$ (annualized). Entrepreneurs' discount factor $\beta_{E}$ is set at 0.975 , as in Iacoviello (2005). The inverse of the Frisch elasticity $\eta$ is set at 1 as in (Galí, 2008). The share of capital in the aggregate production function $\alpha$ is set at 0.20 , and the depreciation rate of physical capital $\left(\delta^{k}\right)$ at 0.05 as in Gerali et al. (2010). The elasticity of substitution across regional goods bundles $\sigma$ is set at 2 as in Engler et al. (2013). Further, we set the adjustment cost for changing prices $\kappa_{p}$ at the value estimated by Gerali et al. (2010) for the euro area, namely 28.65. Concerning the investment

\footnotetext{
${ }^{6}$ We also considered estimating the current framework with disaggregated euro area data, but decided against it because a proper estimation of the cross-border banking effects at work here would be a task beyond the scope of this paper, due to their overlap with the global financial liberalization since the 2000s. We leave this for further research.
} 
Table 1: Calibration parameters

\begin{tabular}{|c|c|c|}
\hline Parameter & Description & Value \\
\hline$\beta_{P}$ & Patient household discount factor & 0.996 \\
\hline$\beta_{E}$ & Entrepreneurs discount factor & 0.975 \\
\hline$\sigma$ & Elasticity of substitution between Home and Foreign goods bundles & 2 \\
\hline$\theta^{D}$ & Parameter for households' portfolio adjustment cost & 0.001 \\
\hline $\bar{D}$ & Steady-state level of deposits & 1 \\
\hline$\omega^{H}$ & Steady-state import share in Home & 0.33 \\
\hline$\omega^{F}$ & Steady-state import share in Foreign & 0.17 \\
\hline$n$ & Home's relative size & 0.34 \\
\hline$\eta$ & Inverse of the Frisch elasticity & 1 \\
\hline$\alpha$ & Capital share in the production function & 0.20 \\
\hline$\delta^{k}$ & Depreciation rate of physical capital & 0.050 \\
\hline$\kappa^{I}$ & Investment adjustment cost parameter & 5 \\
\hline$m^{E}$ & Entrepreneurs LTV ratio & 0.35 \\
\hline$\kappa_{p}$ & Adjustment cost for changing prices & 28.65 \\
\hline$\gamma$ & Bank's elasticity of substitution between lending to both regions & 2 \\
\hline$\theta$ & Bank capital adjustment cost & 11 \\
\hline$\nu$ & Target capital-to-asset ratio & 0.09 \\
\hline$\delta^{b}$ & Cost for managing the bank's capital position & 0.049 \\
\hline$\phi_{\pi}$ & Inflation gap Taylor rule parameter & 1.5 \\
\hline$\rho$ & Monetary policy inertia & 0.77 \\
\hline$\rho_{m k}$ & Persistence of retailers' cost-push shocks & 0.5 \\
\hline$\rho_{a}$ & Persistence of technology shocks & 0.95 \\
\hline$\sigma_{m p}^{2}$ & Variance of monetary policy shock & 0.1 \\
\hline$\sigma_{m k}^{2}$ & Variance of cost-push shock & 1 \\
\hline$\sigma_{a}^{2}$ & Variance of technology shock & 1 \\
\hline
\end{tabular}

adjustment cost parameter $\kappa^{I}$, we set it at 5 as in Gambacorta and Signoretti (2014) in their analysis of their model's response to technology shocks. ${ }^{7}$

The required LTV ratio for entrepreneurs set by the retail bank branches, $m^{E}$, is set at 0.35 in the baseline case, which is similar to the average ratio of long-term loans to the value of shares and other equities for nonfinancial corporations in the euro area, see also Gerali et al. (2010) as well as

\footnotetext{
${ }^{7}$ Gambacorta and Signoretti (2014) set $\kappa^{I}$ at 0.5 when analyzing cost-push shocks, but argue that when both technology and cost-push shocks hit their model at the same time, their overall results are not affected by the choice of a particular value of $\kappa^{I}$, see Gambacorta and Signoretti (2014, p.155-56).
} 
Gambacorta and Signoretti (2014). The target leverage ratio $\nu$ and the cost for managing the bank capital position $\delta^{b}$ are set at $9 \%$ and 0.049 , respectively, following again Gerali et al. (2010). Due to the lack of a more direct measure, we set the bank capital adjustment $\operatorname{cost} \theta$ at 11 , the value estimated by Gerali et al. (2010). The bank's elasticity of substitution between loans to Home and Foreign, $\gamma$, is set equal to the elasticity of substitution between Home and Foreign goods bundles, $\sigma$, at 2 . The degree of monetary policy inertia is set at 0.77 , and $\phi_{\pi}$ is set at 1.5 , as it is standard in the literature.

We set the relative size of the Home and Foreign economies at 0.34 and 0.66 , respectively, to reflect the asymmetric economic size of the regions within the euro area, assuming for the sake of illustration that Home represents the Southern euro area countries such as Spain, Italy, Portugal or Greece, and Foreign the Northern euro area countries, in particular Germany (see also Engler et al., 2013). Finally, we set the variance of the technology and the cost-push shocks equal to 1 percent as in Gambacorta and Signoretti (2014), and the variance of the monetary policy shocks equal to 0.1 percent, reflecting qualitatively the relative size of the empirical estimates by Gerali et al. (2010).

\subsection{Monetary policy shock}

In order to illustrate the different mechanism at work in the present framework, in the following we discuss the dynamic adjustments of the model's endogenous variables to an unexpected contractionary shock on the policy rate of the monetary union's central bank.

As summarized in Figure 2, the unexpected increase in the policy rate of the monetary union's central bank affects both economies through a variety of channels. First, a contractionary shock to the policy rate $r_{t}$ leads to an increase in the internal rate of interest between the wholesale and the region-specific retail bank branches, and thus by extension also to an increase in the loan interest rates $R^{b H}$ and $R^{b F}$ offered to the entrepreneurs by the retail bank branches in the Southern and Northern regions, respectively. This pass-through effect from $r_{t}$ to $R^{b H}$ and $R^{b F}$ is larger than one, as the rise in the spread between the loan rate in both regions and the policy interest rate clearly illustrates. At this point it is noteworthy that despite the fact that the initial shock in the policy rate affects both regions in an identical fashion, the reaction of loan interest rates, the loan spreads and by extension the aggregate amount of awarded loans is, though qualitatively similar, quantitatively different in both regions, with a larger effect on the spread in the Southern region. This rather unexpected result arises from the different economic sizes assumed for both economic regions and the resulting different relative shares of aggregate lending allocated to each region. ${ }^{8}$

The deterioration in the credit financing-conditions for firms leads to a decrease in the demand for credit and thus in the amount of loans granted in equilibrium. This results in a reduction in the level

\footnotetext{
${ }^{8}$ Theoretically, if both regions were completely identical in their economic structure and had the same relative economic size, i.e. $n=0.5$, then the reactions would also be identical and no shift in relative prices would occur. This is indeed corroborated by our model when $n$ is set at 0.5 .
} 

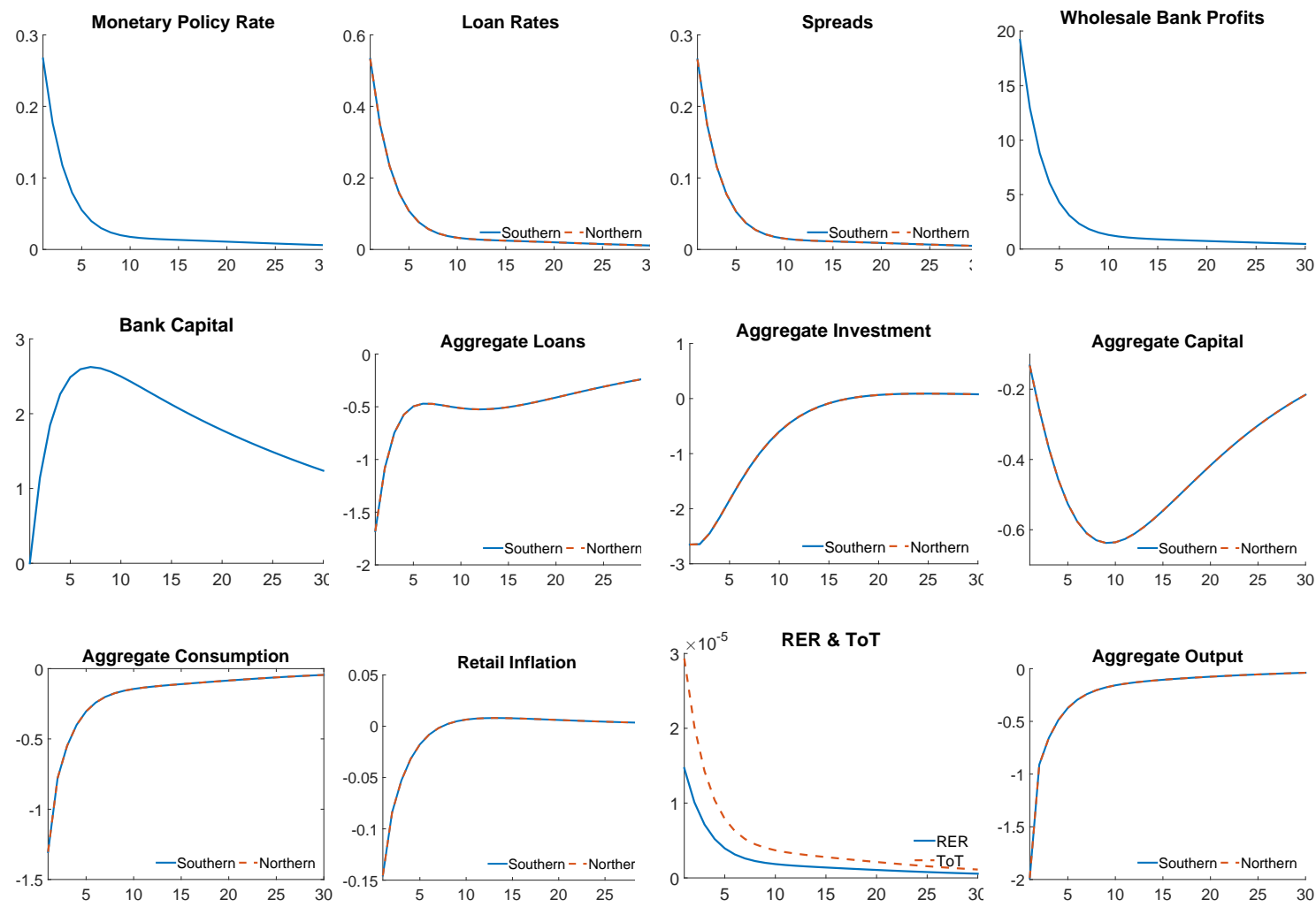

Figure 2: Dynamic adjustments after a union-wide monetary policy shock. All rates are shown as absolute deviations from steady state, expressed in percentage points. All other variables are percentage deviations from their respective steady state levels.

of aggregate investment and by extension in the capital accumulation in both economies, as illustrated in Figure 2.

The increase in the policy rate leads of course also to a reduction in aggregate (both households' and entrepreneurs') consumption - by their respective consumption Euler equations - which, jointly with the reduction in aggregate investment, leads to an overall decrease in current aggregate output, employment and wages. Note that the effect of the monetary policy shock on aggregate output is very similar across both regions despite larger differences in the effect on investment. This is because aggregate consumption in our model is a relatively larger part of output compared to investment. The reduction in households' wage income causes a net reduction in their bank deposits despite the increased opportunity costs related with the increase in the deposit rate (which is assumed to be equal to the policy rate).

Finally, as expected the increase in the policy rate causes a fall in retail inflation in the two regions. ${ }^{9}$ Since the LOP assumption holds, inflation in both regions reacts symmetrically to the shock, even

\footnotetext{
${ }^{9} \mathrm{CPI}$ inflation (not depicted) reacts in a similar manner. All model simulation results are available upon request.
} 
though the level of inflation may differ.

Turning our attention back to the banking sector, the dynamic reactions of the wholesale bank's profits $J_{t}^{B}$ and capital $K_{t}^{b}$ illustrated in Figure 2 show clearly that while the reduction in the quantities of both deposits and loans affects the international wholesale banking sector negatively, the net effect of a policy rate increase is positive due to the larger increase in the internal and loan interest rates, leading to an increase in the bank's profits and capital.

\subsection{Asymmetric Technology Shock}

Next, we briefly discuss the dynamics resulting from an unexpected TFP push shock of one standard deviation in the Northern region. Figure 3 summarizes the dynamics of the main variables of the model.
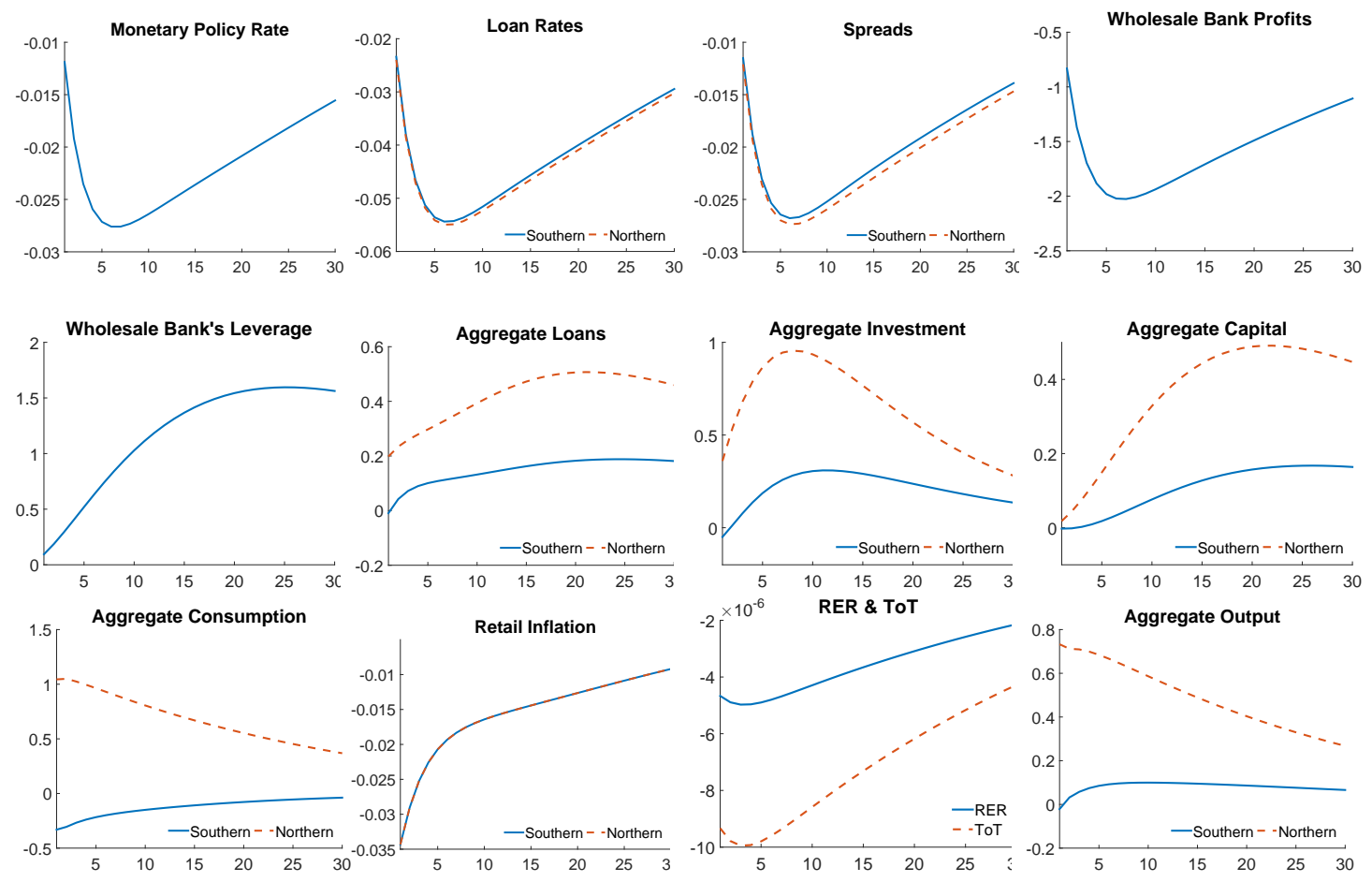

Figure 3: Dynamic adjustments after a TFP shock in the Northern region. All rates are shown as absolute deviations from steady state, expressed in percentage points. All other variables are percentage deviations from their respective steady state levels.

As can be clearly observed, an unexpected asymmetric TFP shock in the Northern region leads to an immediate decrease in both retail and CPI inflation (not depicted) in both regions, as well as to a relative (though very small in absolute terms) improvement in the competitiveness position of the Northern economy. Note that since the LOP applies in our model, prices in both regions adjust 
symmetrically to the TFP shock in the Northern region, even though the level of CPI inflation may differ due to the asymmetric region sizes. The standard countercyclical reaction of the monetary union's central bank implies a decrease in the policy rate sufficient to yield a decrease in the real interest rate. Again, this effect is amplified via the banking sector, as the decrease in loan rate spreads in both regions clearly illustrates (the larger decrease in the Southern regions' loan spread is again due to the different region sizes).

Both the increase in TFP as well as the following decrease in the loan interest rates lead to an increase in the amount of awarded loans not only in the Northern economy (where the TFP shock takes places), but also in the Southern region due to the increased aggregate demand for both Northern as well as Southern goods. This, together with the decrease in the wholesale bank's profits and thus, by extension, in the wholesale bank's capital, leads to a rise in the leverage ratio of the wholesale bank branch.

It is worthwhile pointing out that while the increase in economic activity in the Southern region is purely due to the traditional goods trade channel, capital does flow between the two regions, as deposits are pooled by the wholesale branch and redistributed by the retail branches in the two regions under a constant LTV ratio. In that sense, cross-border banking exacerbates the transmission of the Northern technology shock to the Southern economy. In the next section, we investigate alternative scenarios where credit standards (approximated by the LTV ratio) are endogenously determined according to different rule-of-thumbs.

\subsection{Cross-Border Lending, Rule-of-Thumb Banking and Business Fluctuations}

Here, we investigate the implications of cross-border banking for macroeconomic activity. Indeed, as previously discussed (see also CIEPR, 2012), the recent experience of the housing boom-and-bust cycles in Spain and Ireland - which were financed to a large extent by cross-border capital flows from Germany - seems to suggest that global cross-border lending may not have been subject to the same screening standards for credit worthiness as internal lending, and that this practice may have thus contributed decisively to the recent macroeconomic instability of those countries.

In order to model this phenomenon in the most parsimonious manner, we assume in the following that the LTV borrowing constraint for entrepreneurs, captured by the parameter $m^{E}$, is not constant as assumed in the previous sections, but that it follows a time-varying process driven by the regionspecific previous output gap:

$$
m_{t}^{E, k}=m^{E}+\left(\frac{Y_{t-1}^{k}}{\bar{Y}^{k}}-1\right), \quad k=\{H, F\}
$$

where $\bar{Y}^{k}$ represents the $k$-region potential output. While this is of course a convenient modeling shortcut, the rationale behind this specification is straightforward: In the real world, banks usually 
employ a screening mechanism to assess the profitability of the investment projects to be financed, and thus the creditworthiness of the loan applicants. To reflect this, we assume that the bank associates firms' investment profitability with the overall business cycle stance of the region's economy. Accordingly, it is natural to assume that a positive output gap - resulting for instance from a positive TFP shock - leads to a relaxation of the borrowing constraint imposed on the entrepreneurs by the bank as its assessment of the firms' default risk is reduced. This specification is thus supposed to reflect the procyclicality in lending behavior observable in the euro area in recent times (Čihák and Brooks, 2009). Obviously, the determination of $m_{t}^{E, k}$ would be region-specific in the normal case, with the retail bank branches in Home and Foreign determining $m_{t}^{E H}$ and $m_{t}^{E F}$ according to the observation of Home's or Foreign's output gap, respectively. We refer to this normal case as scenario 1 in the following.

Alternatively, we consider an additional scenario where the lending standards in both countries regions are determined uniformly solely on the observation of the Northern region's output gap, i.e.

$$
m_{t}^{E, k}=m^{E}+\left(\frac{Y_{t-1}^{F}}{\bar{Y}^{F}}-1\right), \quad k=\{H, F\}
$$

This alternative specification of $m_{t}^{E, k}$ solely as a function of $\left(Y_{t-1}^{F}-\bar{Y}^{F}\right) / \bar{Y}^{F}$ is meant to represent the rule-of-thumb determination of lending standards in cross-border banking within the euro area discussed for instance by Allen et al. (2011) and CIEPR (2012). In particular, this specification reflects the implicit risk pooling associated with the establishment of monetary unions, and observable in the excessively low sovereign risk premia of EMU countries and resulting interest rate convergence during the 2000s, see e.g. De Grauwe and Ji (2012) and Proaño et al. (2014). We term this scenario scenario 2 .

Figure 4 illustrates the dynamic adjustment to a technology shock in the Northern region of selected variables of our model under, first, a constant LTV borrowing constraint (baseline scenario), second, varying region-specific lending standards (scenario 1), and, third, dominant region-driven lending standards (scenario 2). In all cases we assume that the output gap of the Northern region is increased by a positive one-standard deviation shock in that region's TFP, $A_{t}^{F}$, leaving all other variables (and especially TFP in the Southern region) unchanged.

As shown in Figure 4, a positive shock to TFP in the North leads to an expansion in aggregate income and investment in that region, the latter being partly financed by an expansion of lending to the entrepreneurs by the banking sector over time. Note that this credit expansion takes place also in the baseline case where $m^{E, k}=$ const., but is of course larger in magnitude in the two alternative scenarios, where $m^{E, k}$ is a direct function of the Northern region's output gap. Due to the higher aggregate income in the North, there is also a higher demand for goods produced there which requires an expansion of the capital stock and thus in the production capabilities of the region. This effect takes place in all three scenarios, but is of course largest in scenario 2, where the LTV borrowing 

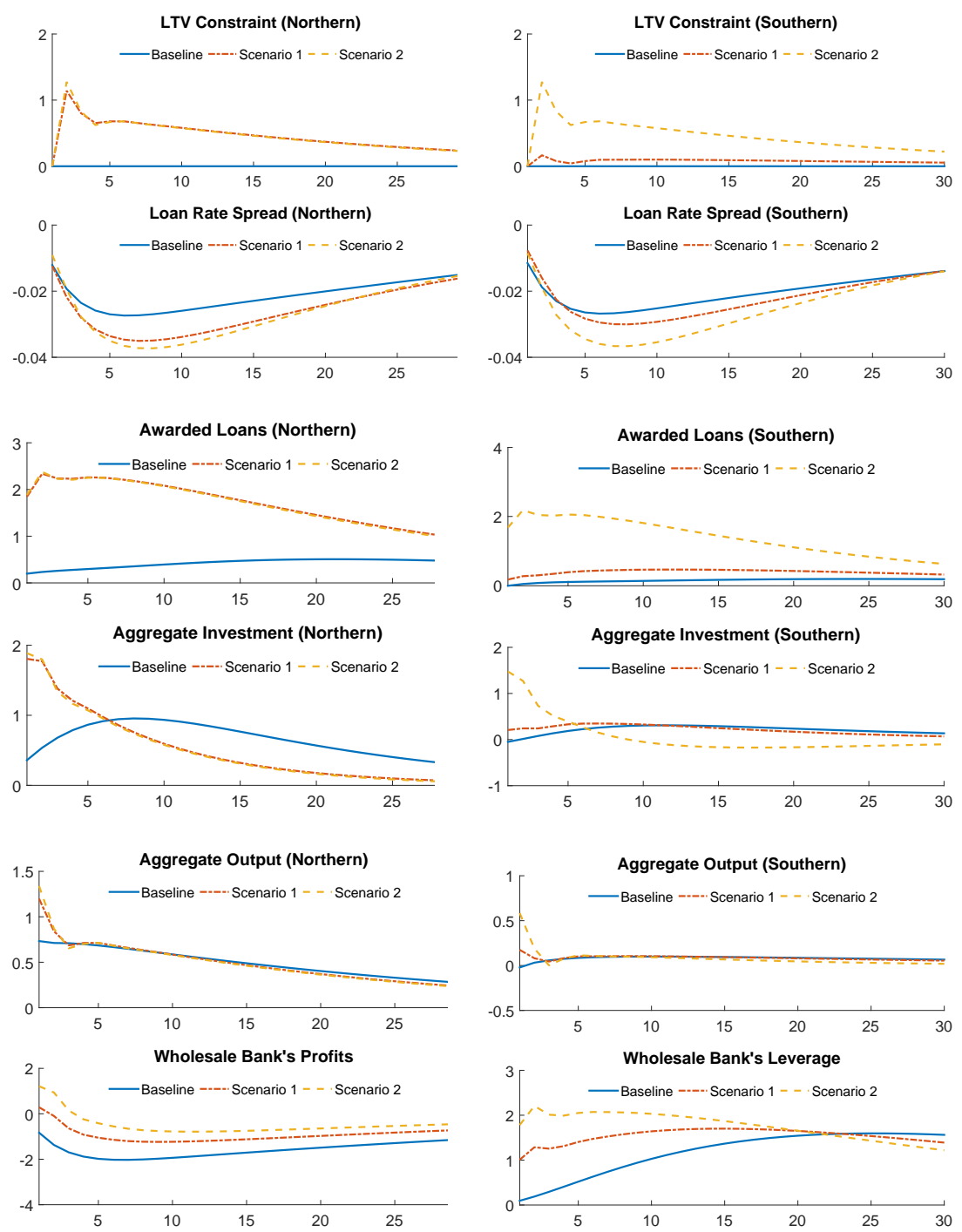

Figure 4: Dynamic adjustments to a positive TFP shock in the Northern region under constant (baseline), region-specific (scenario 1) and rule-of-thumb (scenario 2) lending standards. All rates are shown as absolute deviations from steady state, expressed in percentage points. All other variables are percentage deviations from their respective steady state levels.

constraint (assumed to be a function of the observed output gap in the Northern region) is relaxed not only in the Northern economy (where indeed an increase in TFP took place), but also in the Southern region.

In all three cases loan rate spreads decrease in both regions due to the increase in loans awarded by the retail branches, where the effect is the largest in both countries in scenario 2 when LTV constraints in both regions are relaxed after the shock. Due to the sizable expansion in the amount of awarded 
loans the profits of the international wholesale bank increase during the first periods after the TPF shock especially in scenario 2 , becoming negative when price effects (in this case changes in loan rate spreads) dominate over quantity effects (i.e. loans awarded). In contrast, the reaction of the profits of the international wholesale bank is unambiguously negative in the baseline scenario where the amount of awarded loans does not increase significantly.

As can be clearly observed in Figure 4, the higher quantity of awarded loans leads to a strong immediate increase in the wholesale bank's leverage in scenarios 1 and 2. In the baseline scenario, the leverage of the wholesale bank also increases over time. However, this is due to the lower bank's profits and, by extension, lower bank capital, see eq. (30). Scenario 2 is particularly noteworthy as it shows that an extension in cross-border lending caused by a rule-of-thumb lending standard leads to an excessive credit expansion and a higher leverage in the financial system, and thus to a more fragile macrofinancial situation in comparison to the baseline scenario and the scenario of region-specific lending standards.

In order to assess the effects of our alternative specifications of the LTV borrowing constraint for the business cycle dynamics of the model, Table 2 we compute the theoretical second moments of the Hodrick-Prescott filtered series (using $\lambda=1600$ given the underlying quarterly frequency of the model) of the main variables of the model allowing only for TFP shocks in the Northern region.

Table 2: Theoretical standard deviations (of the Hodrick-Prescott filtered series of the key model variables)

\begin{tabular}{c|rrr}
\hline \hline Variable & Baseline & Scenario 1 & Scenario 2 \\
\hline$m_{e}^{H}$ & 0.000 & 0.160 & 1.302 \\
$m_{e}^{F}$ & 0.000 & 1.212 & 1.302 \\
$D_{t}$ & 0.142 & 0.910 & 1.572 \\
$I_{t}^{H}$ & 0.330 & 0.412 & 1.865 \\
$I_{t}^{F}$ & 1.061 & 2.357 & 2.389 \\
$K_{t}^{H}$ & 0.080 & 0.095 & 0.263 \\
$K_{t}^{F}$ & 0.254 & 0.378 & 0.376 \\
$B_{t}^{H}$ & 0.107 & 0.419 & 2.811 \\
$B_{t}^{F}$ & 0.302 & 2.997 & 3.016 \\
$B_{t}$ & 0.193 & 1.683 & 2.913 \\
$K_{t}^{b}$ & 0.585 & 0.369 & 0.345 \\
$B_{t} / K_{t}^{b}$ & 0.701 & 1.588 & 2.677 \\
$r_{t}^{d}$ & 0.031 & 0.037 & 0.043 \\
$r_{t}^{b H}-r_{t}^{d}$ & 0.031 & 0.033 & 0.041 \\
$r_{t}^{b F}-r_{t}^{d}$ & 0.031 & 0.039 & 0.042 \\
$Y_{t}^{H}$ & 0.112 & 0.168 & 0.550 \\
$Y_{t}^{F}$ & 0.981 & 1.272 & 1.366 \\
\hline \hline
\end{tabular}

As the statistics reported in Table 2 clearly illustrate, both scenarios with endogenous LTV constraints feature a significantly larger overall volatility compared to the baseline scenario with a constant LTV constraint (and thus with a zero standard deviation). Further, the volatility of most aggregate 
macroeconomic variables seems to be the largest in scenario 2, where the LTV constraint in both regions is a function of the previous output gap of the Northern region. Accordingly, rule-of-thumb cross-border banking provides an additional channel via which shocks hitting one region may feedback into the other region's economy.

Since these second moments are computed under the assumption of the only shock being a TFP shock in the Northern region (and no shocks whatsoever hitting the Southern region), it is natural that macroeconomic volatility is higher in the North. Against this background, it is interesting to note that the increment in volatility of key Southern variables such aggregate investment, aggregate capital, awarded loans and aggregate output from scenario 1 to scenario 2 is sizeably larger than in the Northern region. This again highlights the destabilizing impact of the rule-of-thumb lending standard rule.

Summing up, the numerical results discussed in this section suggest that cross-border lending activities, especially with time-varying and potentially cycle-enhancing borrowing constraints, can contribute to the magnification of macroeconomic fluctuations. This may eventually lead to sudden busts as it was the case in Spain and Ireland. Further, they highlight the need of a strict regulation of the financial system and the lending standards, in particular given the perfect mobility of capital within monetary unions such as the euro area.

Nonetheless, it could be possible that monetary policy could support such regulatory efforts by the appropriate design of a monetary policy rule. Indeed, recent theoretical studies within the DSGE modeling paradigm have shown that the incorporation of the banking sector - and the explicit modeling of interest spreads - has important consequences for the design of monetary policy, see for instance Gambacorta and Signoretti (2014). In the next section, we thus address this question.

\section{Is there a role for monetary policy in stabilizing the effects of cross- border banking?}

Despite the highly stylized formulation of the banking sector in our model of a monetary union, the simulation exercises of the previous sections clearly illustrate how cross-border lending can act as an amplifying factor in the business cycle fluctuations within monetary unions, especially when lending standards are not adequately determined at the regional level. In this context, the obvious question is: What are the consequences of cross-border lending for the conduction of monetary policy? Can monetary policy alleviate some of the destabilizing effects of financial integration?

Since we model a banking sector (both wholesale and retail branches) with monopolistic power as in Gerali et al. (2010) and Gambacorta and Signoretti (2014) in the present theoretical framework, monetary policy has only imperfect control of the effective loan interest rates at the regional level. In addition to these studies which analyzed only closed economies, in the present paper we explore 
the open-economy, union-wide implications of such a modeling approach for the banking sector in the presence of trade links and cross-border banking. In other words, our framework allows to investigate how monetary policy should be conducted in the presence of an imperfect interest rate pass-through to the monetary union sphere.

In order to address this imperfect pass-through problem, recent studies introducing a banking sector into the DSGE model such as Cúrdia and Woodford (2010), Gertler and Karadi (2011), Goodfriend and McCallum (2007) and Gambacorta and Signoretti (2014) have proposed incorporating the spread between the loan and the policy rate in an otherwise standard monetary policy rule. By contrast, authors such as Chadha et al. (2012) and Goodhart (2008) argue that a central bank may not be able to simultaneously obtain the goals of price and financial stability with a single interest rate instrument and promote the use of macroprudential policies instead.

In order to address this question in our framework, we include the loan rate spreads in both regions $H$ and $F$, namely $r_{t}^{b H}$ and $r_{t}^{b F}$ - weighted by the respective relative regional sizes - in the Taylor rule in eq. (31), delivering

$$
\left(1+r_{t}^{d}\right)=\left(1+r_{t-1}^{d}\right)^{\rho}\left(1+\bar{r}^{d}\right)^{1-\rho}\left(\left[n \pi_{t}^{H}+(1-n) \pi_{t}^{F}\right]^{\phi_{\pi}}\right)^{1-\rho}\left(\left[n r_{t}^{b H}+(1-n) r_{t}^{b F}-r_{t}^{d}\right]^{\phi_{s}}\right)^{1-\rho} \varepsilon_{t}^{r d}
$$

as $n\left(r_{t}^{b H}-r_{t}^{d}\right)+(1-n)\left(r_{t}^{b F}-r_{t}^{d}\right)=n r_{t}^{b H}+(1-n) r_{t}^{b F}-r_{t}^{d}$, where $\phi_{s}$ represents the reaction parameter of the policy rate to increases in the weighted average of the loan rate spreads in the two monetary union regions.

In order to evaluate the effect of a "leaning-against-the-wind" monetary policy, we compute theoretical variances across a range of parameter values for $\phi_{y}$ and $\phi_{s}$ in both the baseline scenario and the rule-of-thumb cross-border banking scenario 2. Figure 5 reports the ratio of the theoretical variances of the HP-filtered series of key model variables in scenario 2 compared to the variances in the baseline scenario. The variances arise from uncorrelated TFP shocks, cost-push shocks in both regions, and a common monetary policy shock hitting the economy. ${ }^{10}$

As can be seen in Figures 1 and 2 in the Online Appendix, in both the baseline scenario and in the rule-of-thumb banking scenario 2 the variances of most macroeconomic variables increase if the central bank puts a larger weight $\phi_{s}$ on loan rate spreads, where the effect is larger the smaller the weight on the output gap $\left(\phi_{y}\right)$. Notable exceptions are of course the loan rate spreads and CPI inflation rates, where volatility is reduced with a leaning-against-the-wind policy as long as the weight on the output gap is not zero. However, when comparing scenario 2 to the baseline scenario in Figure 5, we observe that a central bank reacting to loan rate spreads is relatively more beneficial for macroeconomic volatility in the face of rule-of-thumb cross-border banking: As banks set lending standards in both

\footnotetext{
${ }^{10}$ We do not show variances across a range of $\phi_{\pi}$ because the model quickly becomes indeterminate as $\phi_{\pi}$ is increased above a value of 1.5. Figures 1 and 2 in the Online Appendix show the underlying simulations in the baseline scenario and in scenario 2 separately.
} 
regions according to business cycle fluctuations in the dominating region - causing an increase in macroeconomic volatility as discussed above - the central bank may be able to reduce macroeconomic volatility relatively more when reacting to changes in financial variables. For medium values of $\phi_{y}$ around 0.25 , an increase in $\phi_{s}$ leads to a reduction in the variances of output, capital, loans and loan rate spreads in both regions in scenario 2 compared to the baseline scenario. Notably, this effect is not continuous in $\phi_{s}$, but in most cases requires a coefficient close to 0.75 or larger. The case of inflation provides an interesting exception: Here, relative volatility is smallest when the central bank targets only inflation, but becomes nearly as small when the central bank either targets the output gap with a large coefficient, or puts a small coefficient on the output gap and a large one on the loan rate spread.

Overall, our results tell a cautious tale of the central bank's ability in promoting both price and financial stability. While there may be a relative benefit of targeting loan rate spreads in the case of rule-of-thumb cross-border banking, the problem nevertheless remains that the central bank effectively has only one instrument to obtain these two, potentially conflicting, goals. 

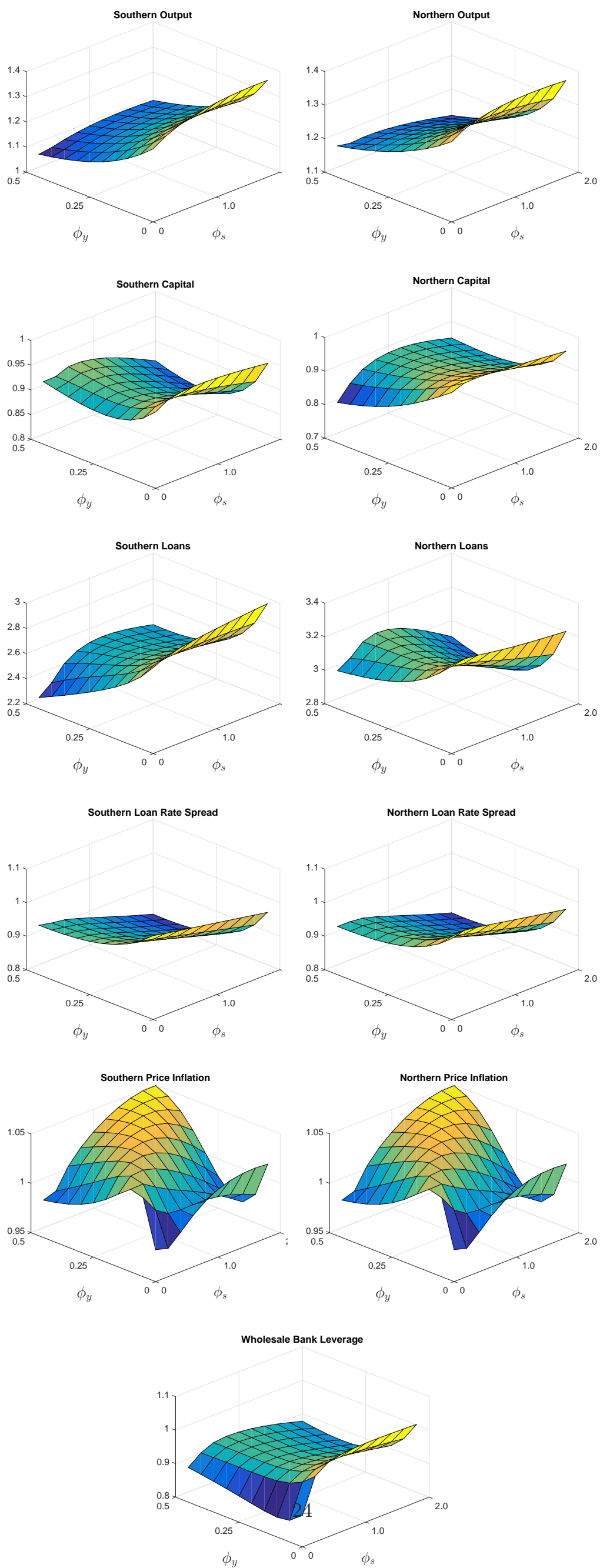

Figure 5: Ratios of Theoretical Variances of Scenario 2 to the Baseline Scenario of Key Model Variables for $\phi_{y} \in[0,0.5]$ and $\phi_{s} \in[0,2]$ 


\section{Concluding Remarks}

What are the macroeconomic consequences of cross-border banking and a rule-of-thumb determination of lending standards? In this paper, we try to shed some light onto these questions by setting up a tworegion DSGE model of a monetary union featuring a global financially constrained banking sector along the lines of Gerali et al. (2010) and Gambacorta and Signoretti (2014), allowing us to differentiate the effects of cross-border lending from the standard trade links of two interacting economies in a monetary union.

Against the background of the recent emergence of macroeconomic imbalances within the EMU, we investigate the macroeconomic consequences of asymmetric rule-of-thumb lending standards applied in a cross-border manner. Specifically, we compare a scenario where the LTV ratio that banks demand of entrepreneurs depends on the regional output gaps to a scenario where desired LTV ratios are driven by the output gap from one dominating region, thereby relaxing borrowing constraints for all firms after a positive output gap in that region. The latter scenario is motivated by the observation of converging real interest rates after the start of EMU, with a corresponding increase in cross-border capital flows as financial markets applied the low risk standards of the Northern region throughout the whole monetary union. Our simulation results suggest that such type of cross-border lending practices amplifies the effects of a region-specific shock in both regions of the monetary union, leading to business fluctuations in the other region generated by the relaxation of lending standards, and not by corresponding changes in macroeconomic fundamentals. Furthermore, such developments lead to a significant increase in the volatility of all main macro variables in both regions of the monetary union. We thus show that under certain conditions the financial sector may exacerbate macroeconomic imbalances originating via the trade channel within the monetary union.

Given the significant effects that such a larger aggregate volatility implies both in macroeconomic and social terms, our results suggest that macroeconomic policy (both fiscal and monetary) concerned with stabilizing the regions within a monetary union should pay attention to the nature of crossborder lending within the union, especially if banks do not assign region-specific lending standards. Further, our simulation results indicate that a central bank adjusting to changes in loan spread rates may somewhat enhance macroeconomic stability in the face of rule-of-thumb cross-border banking compared to the baseline case of constant borrowing constraints. This effect, however, may not replace macroprudential policies, specifically a tighter regulation and standardization of lending practices across the monetary union. 


\section{References}

Allen, Franklin, Thorsten Beck, Elena Carletti, Philip R. Lane, Dirk Schoenmaker and Wolf Wagner (2011), Cross-border banking in europe: Implications for financial stability and macroeconomic policies, Technical report, Centre for Economic Policy Research (CEPR).

Barro, R., G. Mankiw and X. Sala-i Martin (1995), 'Capital mobility in neoclassical models of growth', American Economic Review 85(1), 103-115.

Beetsma, Roel M.W.J. and Henrik Jensen (2005), 'Monetary and fiscal policy interactions in a microfounded model of a monetary union', Journal of International Economics 67(2), 320 - 352.

Benigno, Pierpaolo (2004), 'Optimal monetary policy in a currency area', Journal of International Economics 63(2), 293-320.

Bernanke, B., M. Gertler and S. Gilchrist (1999), The Financial Accelerator in a Quantitative Business Cycle, in J. B.Taylor and M.Woodford, eds, 'Handbook of Macroeconomics', Vol. 1, Part C, Elsevier, pp. $1341-1393$.

Bernanke, Ben, Mark Gertler and Simon Gilchrist (1998), 'The financial accelerator in a quantitative business cycle framework', NBER Working Paper 6455.

BIS (2010), International banking and financial market developments, Quarterly review, Bank for International Settlements.

BIS (2011), 81st annual report, Technical report, Bank for International Settlements.

Blanchard, Olivier J and Gian Maria Milesi-Ferretti (2010), Global imbalances: In midstream?, CEPR Discussion Papers 7693, C.E.P.R. Discussion Papers.

Broner, F., T. Didier, A. Erce and S. Schmukler (2013), 'Gross capital flows: Dynamics and crises', Journal of Monetary Economics 60(1), 113-133.

Chadha, J. S., L. Corrado and J. Meaning (2012), Reserves, liquidity and money: An assessment of balance sheet policies, in BIS, ed., 'Are central bank balance sheets in Asia too large?', number 66 in 'BIS Papers', Bank for International Settlements.

CIEPR (2012), Banks and cross-border capital flows: Policy challenges and regulatory responses, Technical report, Comittee on International Economic Policy and Reform.

Cúrdia, Vasco and Michael Woodford (2010), 'Credit frictions and optimal monetary policy', Journal of Money, Credit \& Banking 42(s1), 3-35.

De Grauwe, Paul and Yuemei Ji (2012), 'Mispricing of sovereign risk and macroeconomic stability in the eurozone', Journal of Common Market Studies 50(6), 866-880. 
Dräger, L. and C. R. Proaño (2015), Cross-border banking and business cycles in asymmetric currency unions, Discussion Paper 21/2015, Deutsche Bundesbank, Frankfurt a.M.

Duarte, M. and A. L. Wolman (2008), 'Fiscal policy and regional inflation in a currency union', Journal of International Economics 74(2), 384-401.

ECB (2010), 'Financial integration'.

Engler, P., G. Ganelli, J. Tervala and S. Voigts (2013), 'Fiscal devaluation in a monetary union', Free University Berlin School of Business \& Economics Discussion Paper 18.

European Commission (2008), EMU@10: successes and challenges after 10 years of economic and monetary union, European Economy 2, Directorate-General for Economic and Financial Affairs.

Ferrero, A. (2009), 'Fiscal and monetary rules for a currency union', Journal of International Economics $\mathbf{7 7}(1), 1-10$.

Gali, J. and T. Monacelli (2008), 'Optimal monetary and fiscal policy in a currency union', Journal of International Economics 76(1), 116-132.

Galí, Jordi (2008), Monetary Policy, Inflation and the Business Cycle, Princeton University Press.

Gambacorta, L. and F. M. Signoretti (2014), 'Should monetary policy lean against the wind? an analysis based on a dsge model with banking', Journal of Economic Dynamics \& ${ }^{\prime}$ Control 43(C), 146-174.

Gerali, A., S. Neri, L. Sessa and F. M. Signoretti (2010), 'Credit and Banking in a DSGE Model of the Euro Area', Journal of Money, Credit and Banking 42(s1), 107-141.

Gertler, M. and P. Karadi (2011), 'A model of unconventional monetary policy', Journal of Monetary Economics 58, 17-34.

Goodfriend, Marvin and Bennett T. McCallum (2007), 'Banking and interest rates in monetary policy analysis: A quantitative exploration', Journal of Monetary Economics 54, 1480-1507.

Goodhart, C. A. E. (2008), Central banks' function to maintain financial stability: An uncompleted task, Technical report, VoxEU.

Iacoviello, Matteo (2005), 'House prices, borrowing constraints and monetary policy in the business cycle', American Economic Review 95(3), 739-764.

in 't Veld, Jan, Robert Kollmann, Beatrice Pataracchia, Marco Ratto and Werner Roeger (2014), 'International capital flows and the boom-bust cycle in spain', Journal of International Money and Finance 48, 314-335.

Jaumotte, Florence and Piyaporn Sodsriwiboon (2010), Current account imbalances in the southern euro area, IMF Working Papers 10/139, International Monetary Fund. 
Kalemli-Ozcan, S., E. Papaioannou and F. Perri (2013), 'Global banks and crisis transmission', Journal of International Economics 89(2), 495-510.

Kamber, G. and C. Thoenissen (2013), 'Financial exposure and the international transmission of financial shocks', Journal of Money Credit, and Banking s45(2), 127-158.

Kleimeier, S., H. Sander and S. Heuchemer (2013), 'Financial crises and cross-border banking: New evidence', Journal of International Money and Finance 32, 884-915.

Kollmann, Robert, Zeno Enders and Gernot Müller (2011), 'Global banking and international business cycles', European Economic Review 55(3), 407-426.

Kose, M. Ayhan, Eswar Prasad, Kenneth Rogoff and Shang-Jin Wei (2009), 'Financial globalization: A reappraisal', IMF Staff Papers 56(1), 8-62.

Lane, P. and G. M. Milesi-Ferretti (2007), 'The external wealth of nations mark II', Journal of International Economics 73, 223-250.

Proaño, C. R., C. Schoder and W. Semmler (2014), 'Financial stress, sovereign debt and economic activity in industrialized countries: Evidence from dynamic threshold regressions', Journal of International Money and Finance 45, 17-37.

Rotemberg, Julio J. (1982), 'Sticky prices in the united states', Journal of Political Economy $\mathbf{9 0}(6), 1187-1211$.

Schmitt-Grohé, S. and M. Uribe (2003), 'Closing small open economy models', Journal of International Economics 61(1), 163-185.

Čhák, Martin and Petra Koeva Brooks (2009), From subprime loans to subprime growth? evidence for the euro area, IMF Working Paper WP/09/69, International Monetary Fund, Washington D.C.

Ueda, K. (2012), 'Banking globalization and international business cycles: Cross-border chained credit contracts and financial accelerators', Journal of International Economics 86(1), 1-16. 
Publisher: Hans-Böckler-Stiftung, Hans-Böckler-Str. 39, 40476 Düsseldorf, Germany Phone: +49-211-7778-331, IMK@boeckler.de, http://www.imk-boeckler.de

IMK Working Paper is an online publication series available at: http://www.boeckler.de/imk 5016.htm

ISSN: $1861-2199$

The views expressed in this paper do not necessarily reflect those of the IMK or the Hans-Böckler-Foundation.

All rights reserved. Reproduction for educational and non-commercial purposes is permitted provided that the source is acknowledged. 